\title{
PENGARUH BUKAAN (OPENING) TERHADAP KAPASITAS LENTUR BALOK BETON BERTULANG
}

\author{
Opening Effect to Bending Capacity of Reinforce Concrete Beams
}

\author{
Handika Setya Wijaya ${ }^{1}$, Sri Murni Dewi ${ }^{2}$, Wisnumurti ${ }^{3}$ \\ ${ }^{1}$ Jurusan Teknik Sipil, Fakultas Teknik, Universitas Tribhuana Tungga Dewi \\ ${ }^{2,3}$ Jurusan Teknik Sipil, Fakultas Teknik, Universitas Brawijaya \\ Jalan Mayjend Haryono 167 Malang 65145 Telp (0341) 567886 \\ Alamat Korespondensi : \\ ndokingsmiling@gmail.com
}

\begin{abstract}
In the construction of modern buildings, piping installation is needed to accomodate mechanical and electrical needs. One alternative plan to skip the installation of piping is by making openings on the beam. The aim of this research is to find out how big the effect of giving some variation of the number of openings given in concrete tensile zone to the strength and stiffness of bending of reinforced concrete beam. The test is a flexible test with a beamsized test object $(15 \times 25 \times 200) \mathrm{cm}$. The variation of this research is the number of openings of $5 \mathrm{~cm}$ in diameter, which are two openings (BB2) and four openings (BB4) and the openings without blocks $(B K)$. From the result of the research indicates that the giving of openings in the tensile zone of concrete reduces the flexural strength although not significant. When compared with $B K$, the reduction of bending strength for $B B 2$ beam is $1.26 \%$ and the reduction for beam of BB4 is $5.66 \%$. For bending stiffness in the precast conditions, there is reduction of bending stiffness. When compared with BK, the reduction of bending rigidity for beam BB2 by $9 \%$ and reduction for BB4 beam by $15.24 \%$. For bending stiffness in postcarpet conditions, there is reduction of bending stiffness as well. When compared with $B K$, the reduction of bending stiffness for BB2 beam is $13.03 \%$ and the reduction for beam of BB4 is $18.68 \%$.
\end{abstract}

Keywords: Opening, Bending Strength, Bending Stiffness.

\begin{abstract}
Abstrak
Dalam konstruksi bangunan-bangunan modern, instalasi perpipaan dibutuhkan untuk mengakamodasi kebutuhan mekanikal dan elektrikal. Salah satu alternatif rencana untuk melewatkan instalasi perpipaan tersebut adalah dengan membuat bukaan (opening) pada balok. Penelitian ini bertujuan untuk mencari seberapa besar pengaruh pemberian beberapa variasi jumlah bukaan yang diberikan di zona tarik beton terhadap kekuatan dan kekakuan lentur balok beton bertulang. Pengujian yang dilakunan adalah pengujian lentur dengan benda uji balok berukuran $(15 \times 25 \times 200) \mathrm{cm}$. Variasi penelitian ini yaitu jumlah bukaan berdiameter $5 \mathrm{~cm}$ yang berjumlah dua bukaan (BB2) dan empat bukaan (BB4) dan balok tanpa bukaan (BK). Dari hasil penelitian menunjukkan bahwa pemberian bukaan pada zona tarik beton mereduksi kekuatan lentur meskipun tidak signifikan. Jika dibandingkan dengan BK, reduksi kekuatan lentur untuk balok BB2 sebesar $1.26 \%$ dan reduksi untuk balok BB4 sebesar 5.66\%. Untuk kekakuan lentur pada kondisi praretak, terjadi reduksi kekakuan lentur. Jika dibandingkan dengan BK, reduksi kekakuan lentur untuk balok BB2 sebesar 9\% dan reduksi untuk balok BB4 sebesar 15.24\%. Untuk kekakuan lentur pada kondisi pascaretak, terjadi reduksi kekakuan lentur juga. Jika dibandingkan dengan BK, reduksi kekakuan lentur untuk balok BB2 sebesar $13.03 \%$ dan reduksi untuk balok BB4 sebesar $18.68 \%$.
\end{abstract}

Kata kunci : Bukaan (Opening), Kekuatan Lentur, Kekakuan Lentur.

\section{PENDAHULUAN}

Dalam konstruksi bangunan-bangunan modern, instalasi perpipaan dibutuhkan untuk mengakamodasi kebutuhan mekanikal dan elektrikal. Biasanya pipa-pipa tersebut ditempatkan di bawah balok dan untuk alasan keindahan dan ditutup dengan langit-langit sehingga menghasilkan ruang yang tidak terpakai. Salah satu alternatif rencana untuk melewatkan instalasi perpipaan tersebut adalah dengan membuat bukaan (opening) 
pada balok. Alternatif ini memberikan reduksi volume ruangan yang signifikan dan memberikan desain yang rapi dan ekonomis. (Mansur, 2006).

Momen kapasitas penampang balok beton dihasilkan dari perkalian resultan gaya tekan $(C)$ dari beton dan lengan $\left(j_{d}\right)$. Sedangkan gaya tekan pada penampang beton dipengaruhi oleh kuat tekan beton $\left(f c^{\prime}\right)$, lebar penampang $(b)$ dan tinggi blok tegangan tekan ekuivalen (a) (Park \& Paulay, 1975). Dengan mengacu pada teori tersebut, hubungannya dengan bukaan pada balok adalah jika bukaan diberikan di daerah bagian tarik penampang, maka tidak ada reduksi kapasitas momen penampang.

Penelitian ini bertujuan untuk mengetahui pengaruh jumlah bukaan terhadap kekuatan dan kekakuan lentur balok beton bertulang.

Untuk menghitung kapasitas ultimit menggunakan teori Whitney adalah dengan rumus sebagai berikut :

$$
\begin{gathered}
T=A_{s} \times f_{y} \\
C=0,85 \times f^{\prime}{ }_{c} \times b \times a \\
a=\frac{A_{s} \cdot f_{y}}{0,85 . f^{\prime}{ }_{c} \cdot b} \\
j_{d}=d-0.5 a
\end{gathered}
$$

Momen tahanan penampang $\left(\mathrm{M}_{\mathrm{n}}\right)$ dapat ditulis sebagai berikut :

$$
M_{n}=T \times j_{d}=C \times j_{d}
$$

Menurut Nawi (1998), hubungan bebandefleksi pada balok bertulang dapat ditunjukkan dengan grafik trilinier yaitu daerah 1 (praretak), daerah 2 (pasca retak), dan daerah 3 (pasca serviceability).

Kemiringan grafik antar daerah dikarenakan momen inersia terus berkurang dengan penambahan beban yang terus diberikan. Rumus lendutan maksimal di setengah bentang untuk balok dengan pembebanan 2 titik adalah:

$$
\Delta \max =\frac{P \cdot a}{24 \cdot E \cdot I}\left(3 L^{2}-4 a^{2}\right)
$$

Dari rumus di atas, karena terjadi reduksi momen inersia dari bukaan, maka momen inersia akan semakin kecil dan akibatnya lendutan akan semakin besar.

Kekakuan didefinisikan sebagai gaya yang diperlukan untuk memperoleh satu unit displacement. Nilai kekakuan merupakan sudut kemiringan dari hubungan antara beban dan lendutan. Makin kaku suatu struktur makin besar nilai kekakuannya (Ujianto,
2006). Jadi kekauan dirumuskan sebagai berikut:

$$
k=\frac{P}{\Delta}
$$

Dari rumus di atas, karena balok dengan bukaan mempunyai lendutan lebih besar, maka kekakuannya akan semakin kecil.

\section{METODE PENELITIAN}

Pengujian yang dilakukan adalah pengujian lentur dengan tumpuan sederhana. Benda uji yang dibuat sebanyak 3 buah untuk variasi balok dua bukaan (BB2), 3 buah untuk variasi balok empat bukaan (BB4), 3 buah untuk variasi balok tanpa bukaan (BK). Ukuran balok semua variasi sama yaitu $(200 \times 15 \times 25) \mathrm{cm}$. Diameter bukaan dari balok dibuat sama yaitu $5 \mathrm{~cm}$ yang dipasang di bagian tarik beton dari balok.

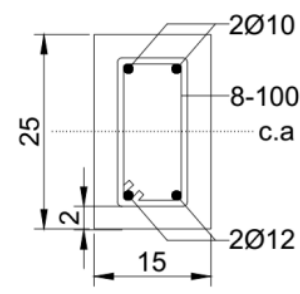

POT. A-A

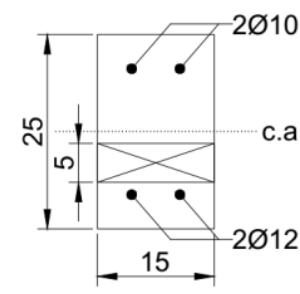

POT. B-B
Gambar 1. Penampang Melintang Balok Tanpa Bukaan dan Dengan Bukaan

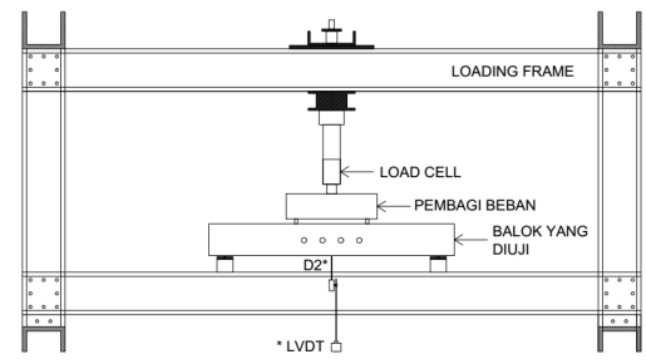

Gambar 2. Setting Up Pengujian Lentur Balok dengan 2 Beban $\mathrm{P}$

Untuk campuran seluruh variasi dibuat sama yaitu 1 PC : 2.68 pasir : 3.15 kerikil. Potongan melintang penampang dapat dilihat pada Gambar 3. Setelah menyiapkan semua material, maka dapat dilakukan pengecoran benda uji. Kemudian dilakukan proses perawatan benda uji selama 28 hari, dapat dilakukan pengujian terhadap benda uji tersebut. Pengujian pembebanan pada balok dilakukan seperti pada Gambar 2. 


\section{HASIL DAN PEMBAHASAN}

\section{Pengujian Kuat Tekan Beton}

Dua puluh tujuh benda uji beton silinder pada umur 28 hari sebagai sampel pengecoran untuk mendapatkan karakteristik campuran beton. Pengujian kuat tekan beton silinder menghasilkan kuat tekan rata-rata sebesar 23.75 MPa. Nilai ini akan digunakan sebagai nilai kuat tekan dalam perhitungan teoritis pada penelitian ini.

\section{Pengujian Kuat Tarik Tulangan}

Dalam penelitin ini digunakan baja polos untuk tulangan tarik, tulangan tekan dan tulangan sengkang. Untuk tulangan tarik digunakan baja polos $\varnothing 11.7 \mathrm{~mm}$, sedangkan tulangan tekan digunakan $\varnothing 9.7 \mathrm{~mm}$ dan tulangan sengkang digunakan $\varnothing 7.7 \mathrm{~mm}$. Dari pengujian tarik baja didapatkan tegangan leleh / luluh (fy) rata-rata untuk tulangan tarik sebesar 390.85 MPa dan tegangan leleh untuk tulangan tekan sebesar $406.17 \mathrm{MPa}$ dan tulangan sengkang sebesar $429.71 \mathrm{MPa}$.

\section{Pengujian Lentur Balok Beton Bertulang}

Pengujian lentur balok beton menghasilkan nilai beban dan lendutan yang terjadi pada balok yang dapat dilihat pada Gambar 5 di bawah ini.

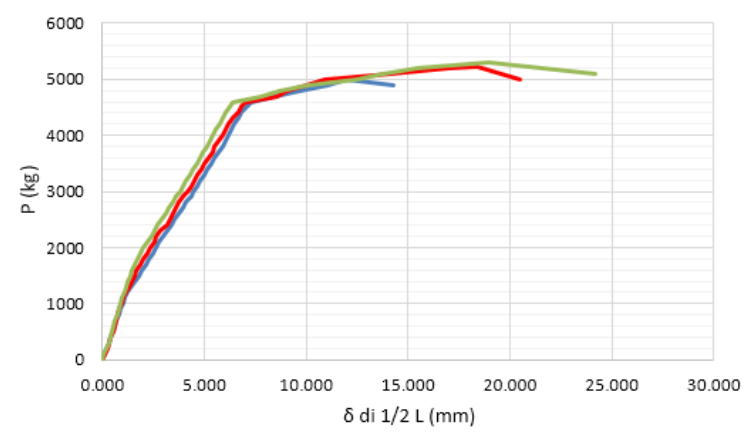

Gambar 3. Grafik Gabungan Hubungan Beban dan Lendutan untuk Semua Variasi

\section{- Hubungan Beban dan Lendutan}

- Pada Kondisi Penampang Utuh

Nilai beban dan lendutan untuk balok BB2, balok BB4 dan balok BK pada kondisi praretak diberikan pada Tabel 1. sebagai berikut
Tabel 1. Nilai Beban dan Lendutan pada Saat Kondisi Praretak

\begin{tabular}{cccc}
\hline \multirow{2}{*}{$\begin{array}{c}\text { Beban }(\mathrm{P}) \\
\mathrm{kg}\end{array}$} & \multicolumn{3}{c}{ Lendutan di setengan bentang } \\
\cline { 2 - 4 } & $\mathrm{BK}$ & $\mathrm{BB} 2$ & $\mathrm{BB} 4$ \\
\hline 0 & 0.000 & 0.000 & 0.000 \\
100 & 0.073 & 0.093 & 0.103 \\
200 & 0.180 & 0.247 & 0.220 \\
- & - & - & - \\
- & - & - & - \\
600 & 0.530 & 0.580 & 0.597 \\
700 & 0.633 & 0.690 & 0.707 \\
\hline
\end{tabular}

Grafik beban dan lendutan pada Tabel di atas ditunjukkan pada Gambar 4.

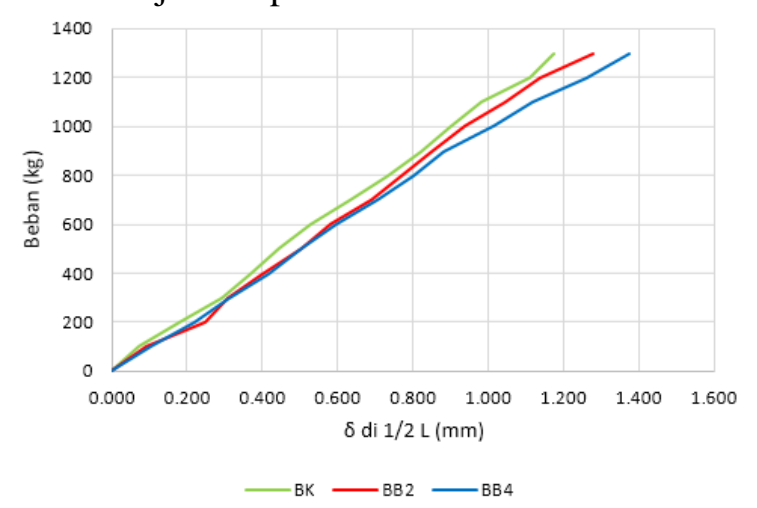

Gambar 4. Grafik Hubungan Beban dan Lendutan pada Kondisi Praretak

\section{- Pada Kondisi Pascaretak}

Nilai beban dan lendutan untuk balok BB2, balok BB4 dan balok BK pada kondisi pascaretak diberikan pada Tabel 2. sebagai berikut

Tabel 2. Nilai Beban dan Lendutan pada Saat

\begin{tabular}{cccc} 
& \multicolumn{3}{c}{ Kondisi Pascaretak } \\
\hline \multirow{2}{*}{$\begin{array}{c}\text { Beban }(\mathrm{P}) \\
\mathrm{kg}\end{array}$} & \multicolumn{3}{c}{$\begin{array}{c}\text { Lendutan di setengan bentang } \\
(\mathrm{mm})\end{array}$} \\
\cline { 2 - 4 } & $\mathrm{BK}$ & $\mathrm{BB} 2$ & $\mathrm{BB} 4$ \\
\hline 1400 & 1.263 & 1.420 & 1.580 \\
1500 & 1.357 & 1.570 & 1.770 \\
1600 & 1.470 & 1.673 & 1.913 \\
- & - & - & - \\
- & - & - & - \\
2400 & 2.727 & 3.153 & 3.363 \\
2500 & 2.887 & 3.317 & 3.547 \\
\hline
\end{tabular}

Grafik beban dan lendutan pada Tabel di atas ditunjukkan pada Gambar 5. 


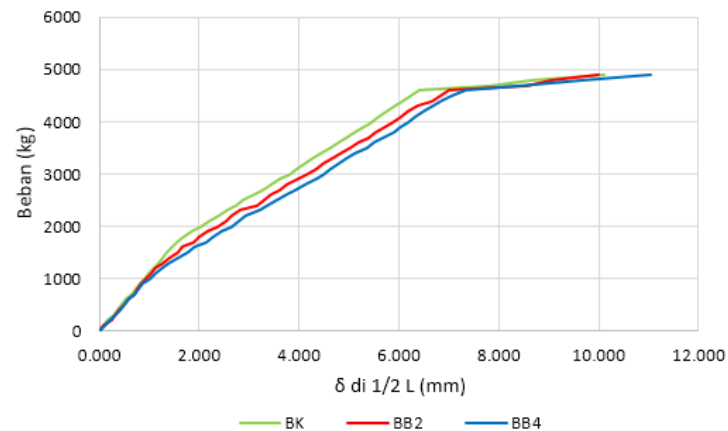

Gambar 5. Grafik Hubungan Beban dan Lendutan pada Kondisi Pascaretak

\section{- Pembahasan}

Untuk kondisi praretak, dari hasil di atas dapat dianalisis bahwa dengan pemberian beban yang besarnya sama, misalkan pada beban $700 \mathrm{~kg}$, lendutan maksimal di setengah bentang nilainya bereda yaitu $\mathrm{BK}=0.633$ $\mathrm{mm}, \mathrm{BB} 2=0.69 \mathrm{~mm}$ dan BB4 $=0.707 \mathrm{~mm}$. Hal ini dikarenakan Inersia gross $\left(\mathrm{I}_{\mathrm{g}}\right)$ yang pada kondisi praretak berkurang akibat adanya bukaan. MacGregor \& Wight (2012) menyatakan bahwa ketika momen inersia berkurang akan dapat menyebabkan sebuah reduksi kekakuan dalam diagram bebanlendutan.

Untuk kondisi pascaretak, dari hasil di atas dapat dianalisis bahwa dengan pemberian beban yang besarnya sama, misalkan pada beban $2500 \mathrm{~kg}$, lendutan maksimal di setengah bentang nilainya berbeda yaitu $\mathrm{BK}=$ $2.887 \mathrm{~mm}, \mathrm{BB} 2=3.317 \mathrm{~mm}$ dan BB $4=3.547$ $\mathrm{mm}$. Hal ini dikarenakan Inersia efektif $\left(\mathrm{I}_{\mathrm{e}}\right)$ yang pada kondisi pascaretak berkurang dengan adanya bukaan.

\section{- Kekakuan Balok}

Ujianto (2006) menyatakan kekakuan balok dapat dilihat dari kemiringan kurva hubungan beban dan lendutan balok. Semakin curam kemiringan kurva maka semakin kaku balok tersebut, atau sebaliknya.

\section{- Pada Kondisi Praretak}

Dari hasil pengujian didapatkan kekakuan lentur untuk kondisi praretak yaitu pada beban $700 \mathrm{~kg}$ dapat dilihat pada Tabel 3 .
Tabel 3. Nilai Kekakuan Masing-Masing Varisi pada Kondisi Praretak

\begin{tabular}{ccc}
\hline Benda Uji & Beban $(\mathrm{kg})$ & $\begin{array}{c}\text { Kekakuan } \\
(\mathrm{kg} / \mathrm{mm})\end{array}$ \\
\hline BK & 700 & 1122 \\
BB2 & 700 & 1021 \\
BB4 & 700 & 951 \\
\hline
\end{tabular}

Grafik nilai kekakuan pada Tabel di atas ditunjukkan pada Gambar 6.

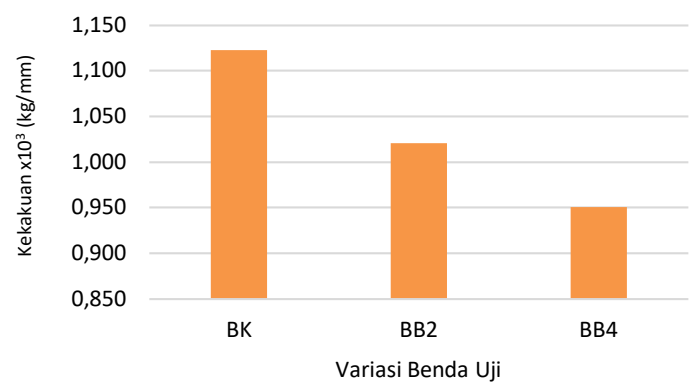

Gambar 6. Perbandingan Kekakuan MasingMasing Variasi pada Kondisi Praretak

\section{- Pada Kondisi Pascaretak}

Dari hasil pengujian didapatkan kekakuan lentur pada kondisi pascaretak yaitu pada beban sebesar $2500 \mathrm{~kg}$ dan hasilnya dapat dilihat pada Tabel 4 di bawah ini.

Tabel 4. Nilai Kekakuan Masing-Masing Varisi pada Kondis Pascaretak

\begin{tabular}{ccc}
\hline $\begin{array}{c}\text { Benda } \\
\text { Uji }\end{array}$ & Beban $(\mathrm{kg})$ & $\begin{array}{c}\text { Kekakuan } \\
(\mathrm{kg} / \mathrm{mm})\end{array}$ \\
\hline BK & 2500 & 867 \\
BB2 & 2500 & 754 \\
BB4 & 2500 & 705 \\
\hline
\end{tabular}

Grafik nilai kekakuan pada Tabel di atas ditunjukkan pada Gambar 7.

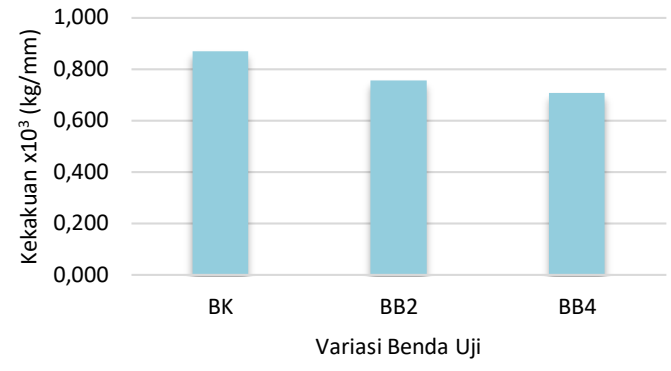

Gambar 7. Perbandingan Kekakuan MasingMasing Variasi pada Kondisi Pascaretak

\section{- Pembahasan}

Untuk kondisi praretak, Dari hasil di atas dapat dianalisis bahwa dengan pemberian beban yang besarnya sama yaitu untuk beban 
$700 \mathrm{~kg}$, kekakuan balok BK $=1122 \mathrm{~kg} / \mathrm{mm}$, balok BB2 $=1021 \mathrm{~kg} / \mathrm{mm}$, dan balok BB4 = $951 \mathrm{~kg} / \mathrm{mm}$. Jika dibandingkan dengan balok kontrol (BK) terjadi reduksi kekakuan sebesar 9\% untuk BB2 dan $15.24 \%$ untuk BB4.

Untuk Kondisi Pascaretak, dengan pemberian beban sebesar $2500 \mathrm{~kg}$, kekakuan balok $\mathrm{BK}=867 \mathrm{~kg} / \mathrm{mm}$, balok BB2 $=754$ $\mathrm{kg} / \mathrm{mm}$, dan balok BB4 $=705 \mathrm{~kg} / \mathrm{mm}$. Jika dibandingkan dengan balok kontrol (BK) terjadi reduksi kekakuan sebesar $13.03 \%$ untuk BB2 dan $18.68 \%$ untuk BB4.

Penyebab menurunnya kekakuan balok selain berkurangnya momen inersia pada penampang, ada juga pengaruh kekauan tarik (tension stiffening) yang berkurang. Kekakuan tarik dialami oleh beton yang masih utuh di antara dua retak (Ng et al., 2010). Beton utuh tersebut masih dapat menahan tegangan tarik. Apabila ada bukaan maka area tension stiffening dari beton akan berkurang sehingga kekakuan juga berkurang jika dibandingkan dengan balok tanpa bukaan.

\section{- Kapasitas Dalam Menahan Beban Maksimum}

Hasil dari kekuatan ultimit masing masing variasi dapat ditunjukkan pada Tabel 5 berikut ini.

Tabel 5. Kapasitas dalam Menahan Beban

\begin{tabular}{cc}
\multicolumn{2}{c}{ Masing-Masing Varisi } \\
\hline Tipe balok & $\begin{array}{c}\text { P max Eksperimen } \\
(\mathrm{kg})\end{array}$ \\
\hline BK & 5300 \\
BB2 & 5233 \\
BB4 & 5000 \\
\hline
\end{tabular}

Grafik nilai kekuatan pada Tabel di atas ditunjukkan pada Gambar 8.

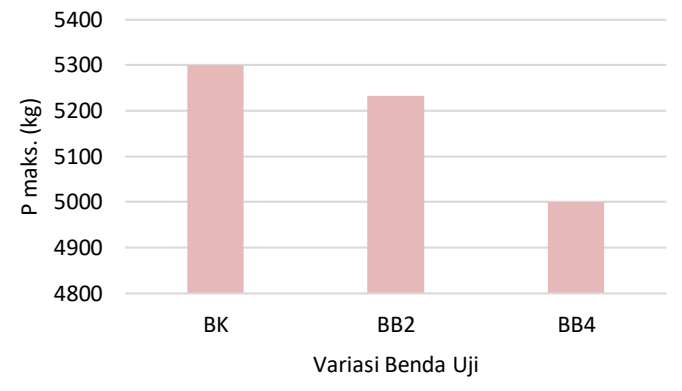

Gambar 8. Perbandingan Beban Ultimit Masing-Masing Variasi

\section{- Pembahasan}

Dari grafik di atas, dapat dianalisis bahwa terdapat reduksi kekuatan dalam menahan beban jika dibandingkan dengan balok kontrol masing-masing sebesar $1.26 \%$ untuk balok dengan dua bukaan (BB2) dan $5.66 \%$ untuk balok dengan empat bukaan (BB4).

Dari teori Whitney, peran kekuatan beton di bawah garis netral dianggap tidak mempunyai pengaruh terhadap kekuatan ultimit dari sebuah balok karena kekuatan tarik sepehuhnya diterima oleh tulangan tarik. Sehingga secara teoritis momen kapasitas penampang antara BK, BB2 dan BB4 mempunyai nilai yang sama. Tetapi hasil pengujian menunjukkan nilai yang berbeda.

Kumar \& Joy (2013) meneliti penggantian parsial beton di bawah garis netral pada balok dengan bola plastik. Pemberian bola plastik di bagian tarik pada beton ternyata mereduksi kekuatan lentur ultimit dari balok tersebut meskipun tidak signifikan. Peneliti tersebut menyatakan bahwa meskipun kekuatan beton di bawah garis netral diabaikan, tetapi beton yang berada di bawah garis netral mempunyai peran yaitu sebagai media transfer tegangan antara zona tekan ke zona tarik.

$\mathrm{Ng}$ et al. (2010) memberikan diagram tegangan beton yang bekerja pada saat pembebanan seperti dilihat pada Gambar 9 di bawah ini.

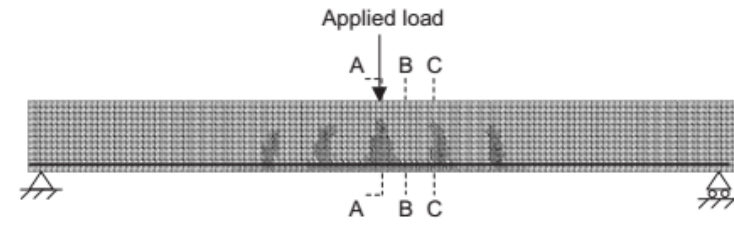

(a)

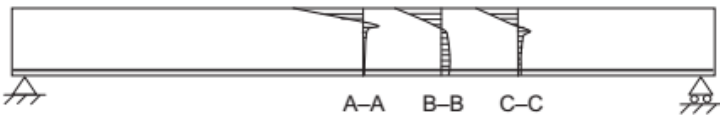

(b)

Gambar 9. (a) Pola Retak (b) Distribusi Tegangan pada Beton. Sumber : (Ng et al., 2010)

Dari Gambar di atas, untuk tegangan beton di bawah garis netral ternyata masih terdapat nilainya. Apabila di bawah garis netral tersebut ada bukaan, maka tegangan tarik pada beton di area tersebut akan terganggu sehingga selanjutnya akan mempengaruhi besarnya tegangan tekan. Maka dari itu kekuatan ultimit antara balok dengan bukaan akan lebih kecil dari balok 
beton biasa meskipun besarnya tidak terlalu signifikan.

\section{- Pola Retak}

Berdasarkan pada pengujian lentur balok beton bertulang yang telah dilakukan, dapat diamati bahwa pola retak yang terjadi pada balok beton dengan variasi bukaan di badan balok. Hasil pola retaknya dapat dilihat pada Gambar 10, 11, dan 12.

Dari semua benda uji retak yang muncul adalah retak lentur di area wilayah yang terkena momen lentur. Untuk balok BB2, BB4 dan BK retak lentur dimulai di daerah tegangan tarik beton selanjutnya menjalar ke wilayah yang terdapat bukaan pada badan dan setelah itu menuju ke daerah tekan dari penampang.

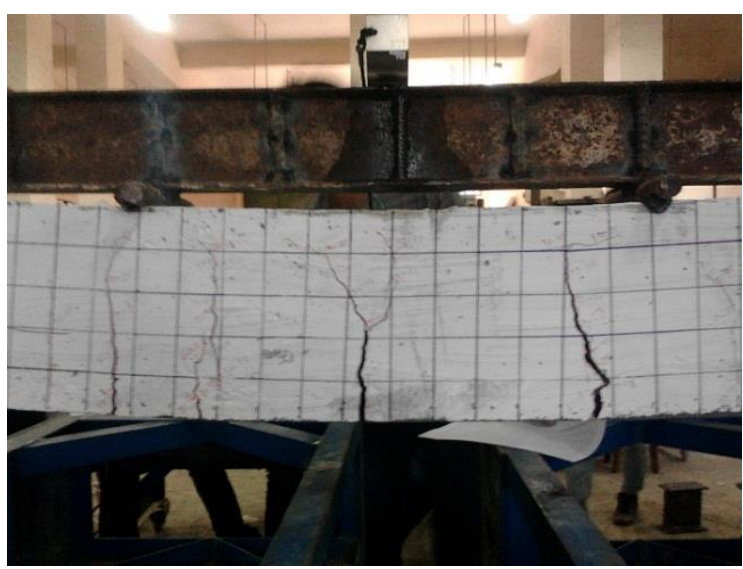

Gambar 10. Pola Retak pada Balok Kontrol (BK)

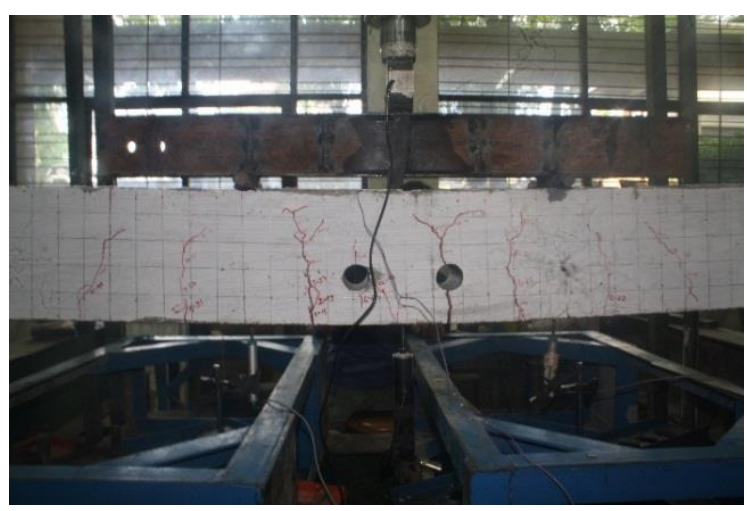

Gambar 11. Pola Retak pada Balok dengan Dua Bukaan (BB2)

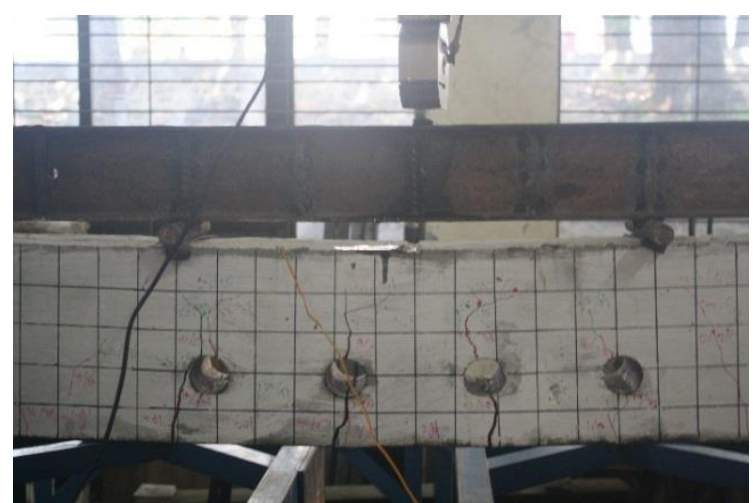

Gambar 12. Pola Retak pada Balok dengan Empat Bukaan (BB4)

Bedanya yaitu dengan adanya bukaan, pada variasi balok dengan bukkaan, BB2 dan BB4, hampir seluruhnya retakan menjalar menuju bukaan yang merupakan sumber dari kelemahan. Sehingga kecepatan retak pada balok dengan bukaan lebih besar dari pada balok tanpa bukaan (BK).

\section{- Perbandingan Hasil Eksperimen dengan Hasil Numerik pada Tahap Elastis}

Dari hasil eksperimen yang telah dilakukan, digunakan metode numerik berbasis softwere dan hitungan analitis untuk memverifikasi hasil eksperimen tersebut. Dalam penelitian ini verifikasi menggunakan bantuan softwtere Staad Pro v8i dengan menggunakan elemen solid. Hasil perbandingan antara eksperimen, analitis dan numerik dapat dilihat pada Gambar di bawah ini untuk variasi BK, BB2, dan BB4.

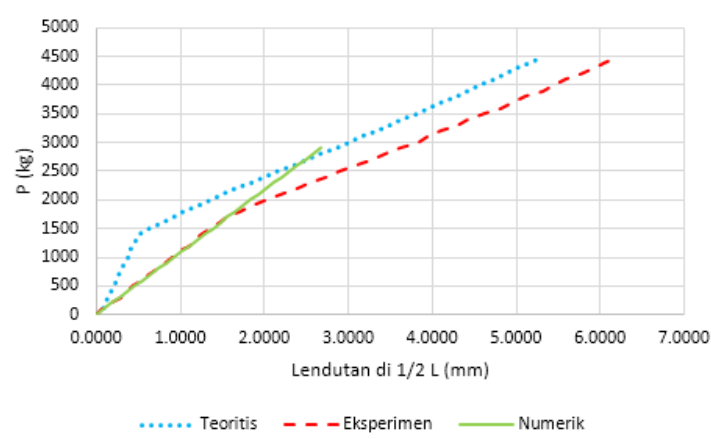

Gambar 13. Perbandingan P vs $\Delta$ Hasil Eksperimen, Analitis dan Numerik pada balok $\mathrm{BK}$ 


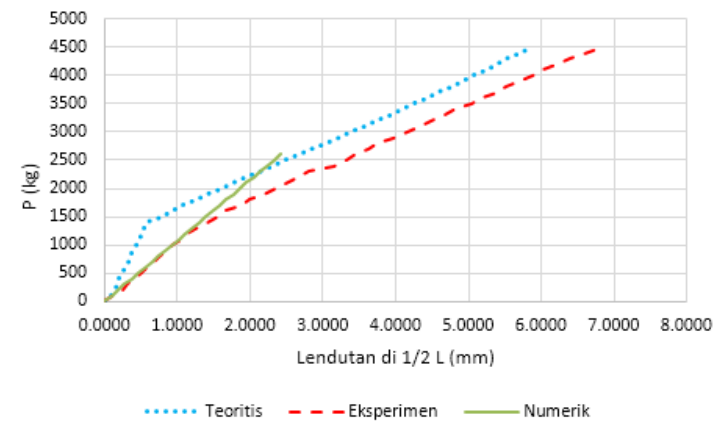

Gambar 14. Perbandingan P vs $\Delta$ Hasil Eksperimen, Analitis dan Numerik pada balok BB2

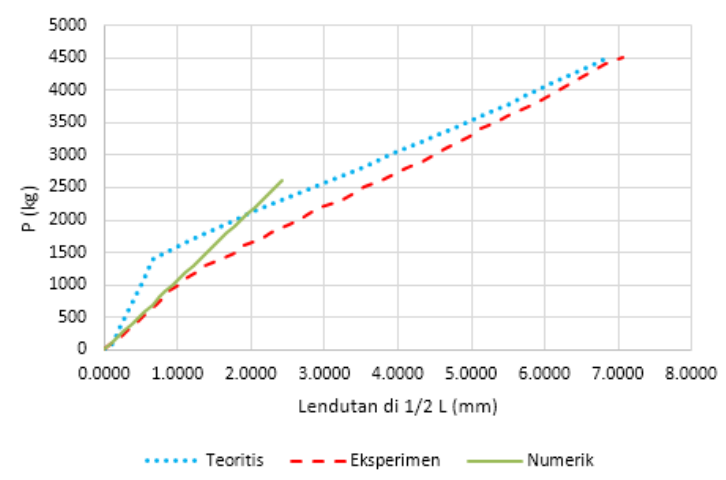

Gambar 15. Perbandingan P vs $\Delta$ Hasil

Eksperimen, Analitis dan Numerik pada balok BB4

\section{KESIMPULAN DAN SARAN}

\section{Kesimpulan}

- Kekakuan lentur yang dihasilkan dari pengujian lentur balok beton sederhana 2 tumpuan dengan variasi jumlah bukaan pada balok balok mengalami penurunan kekakuan pada kondisi praretak. Nilai kekakuan pada taraf beban sebesar $700 \mathrm{~kg}$, jika dibandingakan dengan balok kontrol (BK) terjadi reduksi kekakuan lentur untuk BB2 sebesar 9\% dan untuk BB4 sebesar 15.24\%. Berdasarkan uji statistik, penambahan jumlah bukaan pada balok memiliki pengaruh yang signifikan terhadap kekakuan balok pada kondisi praretak.

- Pada kondisi pascaretak, terjadi penurunan kekakuan lentur akibat adanya bukaan pada balok. Kekakuan pada taraf beban sebesar $2500 \mathrm{~kg}$, jika dibandingakan dengan balok kontrol (BK) terjadi reduksi kekakuan lentur untuk BB2 sebesar $13.03 \%$ dan untuk BB4 sebesar $18.68 \%$. Berdasarkan uji statistik, penambahan jumlah bukaan tidak memiliki pengaruh yang signifikan terhadap kekakuan balok beton sederhana 2 tumpuan pada kondisi pascaretak.

- Kekuatan lentur yang dihasilkan dapat dilihat dari kapasitas balok dalam menahan beban maksimum yang diberikan. Kekuatan lentur pada balok dengan bukaan mengalami reduksi dibanding dengan balok tanpa bukaan. Dalam prosentase, jika dibandingakan dengan balok kontrol (BK), reduksi kekuatan lentur untuk BB2 sebesar $1.26 \%$ dan untuk BB4 sebesar $5.66 \%$. Berdasarkan uji statistik, penambahan jumlah bukaan tidak memiliki pengaruh yang signifikan terhadap kekuatan balok beton sederhana 2 tumpuan.

- Hasil dari pengamatan pola retak menunjukkan keruntuhan yang terjadi pada keseluruhan balok adalah keruntuhan lentur. Untuk balok dengan bukaan, sebagian besar retak melewati bukaan yang merupakan sumber kelemahan dari balok.

\section{Saran}

Dalam penelitian ini ada beberapa yang bisa dikembangkan untuk penelitian selanjutnya. Dalam penelitian selanjutnya diharapkan untuk lebih mempertajam perbedaan pada kekuatan ultimit antara balok dengan bukaan dan tanpa bukaan. Selain itu diharapkan ada penelitian terkait efek dari perkuatan tulangan yang dipasang di sekitar bukaan untuk mereduksi lendutan akibat adanya bukaan. Dari penelitian di atas, disarankan menggunakan konstruksi balok dengan dua bukaan (BB2) dari pada balok dengan empat bukaan (BB4), karena reduksi kekuatan dan kekakuannya tidak terlalu besar.

\section{DAFTAR PUSTAKA}

Kumar, Aswathy S \& Anup, Joy. (2013). Experimental Investigation on Partial Repacement of Concrete Below Neutral Axis of Beam. International Journal of Science and Research (IJSRD). Index Copernicus Value : 6.14 .

MacGregor, James G. \& James, K. Wight. (2009). Reinforced Concrete Mechanics and Design. Pearson Education : New Jersey.

Nawi, Edward G. (1998). Beton Bertulang : Suatu Pendekatan Dasar. Terjemahan Bambang Suryoatmono. Refika Aditama : Bandung. 
Ng, Ng L., Jeffrey, Y. K. L. \& Kwan, AKH. (2010). Tension Stiffening in Concrete Beams. Part 1 : FE Analysis. Proceedings of the Institution of Civil Engineers Structural and Building 163 : 19-28. Attribution 3.0 Hong Kong License.

Park, R dan T, Paulay. (1975). Reinforced Concrete Structures. John Wiley \& Sons : New York.

Ujianto, Muhammad. (2006). Lendutan dan Kekakuan Balok Beton Bertulang dengan Lubang Segi Empat di Badan. Jurnal eco REKAYASA. Vol. 2 No. 2. 